\title{
PENGARUH NILAI-NILAI KEARIFAN LOKAL TERHADAP KINERJA PEGAWAI DI KANTOR DINAS KEPENDUDUKAN DAN CATATAN SIPIL KABUPATEN BULUKUMBA
}

\author{
${ }^{1}$ Reski Devi, ${ }^{2}$ Jaelan Usman, ${ }^{3}$ Ihyani Malik \\ 1) Jurusan Ilmu Administrasi Negara Fisip Unismuh \\ 2) Jurusan Ilmu Administrasi Negara Fisip Unismuh \\ 3) Jurusan Ilmu Administrasi Negara Fisip Unismuh
}

\begin{abstract}
This research aimed to determine the influential value to the performance of employees. The type of research was quantitative descriptive. The population and sample used saturated sample technique so the sample in this research were 93 people. ((The data and documentation and developed by interviewing respondents)). The data collection was done by distributing questionnaires to respondents. The analysis tools used simple regression. The results of the research showed that the value of local wisdom has a positive and insignificant effect. This is evidenced by the results of the regression value of positive 0.089 with a significant level of 0.592 greater than 0.05. This results is reinforced by the results of the determination coefficient test of 0.073 or $7.3 \%$ of the contribution of the value of local wisdom to the performance of employees in the population service office and civil enumeration in Bulukumba Regency. While $92.7 \%$ was influenced by other factors that were not examined in this research.
\end{abstract}

Key word: Nilai-Nilai Kearifan Lokal, Kinerja Pegawai

\begin{abstract}
ABSTRAK
Penelitian ini bertujuan untuk mengetahui nilai-nilai berpengaruh terhadap kinerja pegawai. Jenis penelitian adalah deskriptif kuantitatif. Popolasi dan sampel menggunakan teknik sampel jenuh, sehingga sampel pada penelitian ini sebanyak 93 orang. Data dan dokumentasi serta dikembangkan dengan wawancara terhadap responden. Pengumpulan data dilakukan dengan menyebarkan kuesioner kepada responden. Alat analisis menggunakan Regresi Sedehana. Hasil penelitian menunjukkan nilai kearifan lokal berpengaruh secara positif dan tidak signifikan". Hal ini dibuktikan dengan hasil nilai regresi sebesar positif 0,089 dengan tingkat signifikan 0,592 lebih besar dari 0,05. Hasil ini diperkuat dengan hasil uji kofisien determinasi sebesar 0,073 atau 7,3\% kontribusi nilai kearifan lokal terhadap kinerja pegawai di Kantor Dinas Kependudukan dan Pencatatan Sipil Kabupaten Bulukumba. Sedangkan 92,7 \% dipengaruhi oleh faktor lain yang tidak diteliti pada penelitian kali ini.
\end{abstract}

Kata Kunci: Nilai-Nilai Kearifan Lokal, Kinerja Pegawai 


\section{PENDAHULUAN}

Setiap organisasi atau instansi dalam melaksanakan program selalu diarahkan untuk mencapai tujuannya. Adapun salah satu faktor yang menjadi patokan untuk mencapai tujuan suatu organisasi atau instansi yaitu mengenali dan mengukur kinerja pegawainya yang dimana memasukkan kearifan lokal didalamnya. Organisasi yaitu merupakan beberapa satu kesatuan yang komplit yang berusaha mendistribusikan atau mengalokasikan beberapa sumber daya manusia secara penuh agar tercapainya suatu tujuan. Apabila suatu organisasi mampu mencapai tujuan yang telah ditetapkan, maka dapat dikatakan bahwa organisasi tersebut efektif. Bertepatan dengan perkembangannya, semua organisasi agar dituntut untuk bisa bersaing mempersembahkan pelayanan yang lebih maksimal, tidak terkecuali organisasi pemerintahan.

Demikian halnya dengan aparat pemerintah sebagai abdi masyarakat dan abdi pemerintah, dituntut untuk dapat memberikan pelayanan yang terbaik kepada masyarakat karena hal tersebut sudah merupakan salah satu fungsi yang harus dijalankan oleh pemerintah yang mempunyai tugas menyelenggarakan seluruh proses pelaksanaan pembangunan dalam berbagai sektor kehidupan mulai dari tingkat pusat hingga tingkat daerah. Yang paling tepat untuk mengakomodasi segala kebutuhan masyarakat dari bawah, maka pemerintah daerah adalah pihak yang sangat tepat untuk mempraktekkan kearifan lokal dalam pelaksanaan kinerja pemerintahan.

Pemerintah Kabupaten Bulukumba adalah Kabupaten yang melakukan berbagai macam inovasi dalam sistem pelayanan administrasinya salah satunya yaitu melakukan pelayanan kartu tanda penduduk (KTP), akte kelahiran, dan kartu keluarga (KK) gratis, pemerintahan Daerah berharap masyarakat harus terdata secara baik dan tepat, serta adapun program jemput bola layanan KTP, Akte Lahir, serta KK menjadi bagian dari upaya pemerintahan daerah menerapkan pendekatan layanan kepada masyarakat. Program ini menggerakkan semua operator Kecamatan untuk mendata semua warga yang belum memiliki KTP, Akte lahir, dan KK. Meskipun dianggap masih perlu ditingkatkan lagi layanan administrasi kependudukan gratis dan 
layanan jemput bola kiranya telah memperbaiki sistem data base kependudukan Kabupaten Bulukumba.

Pentingnya pelayanan publik menjadi sorotan ditingkat daerah namun kinerja pemerintah Kabupaten Bulukumba dalam melaksanakan pelayanannya kepada para penduduknya dianggap masih rendah. Cara yang berliku-liku dan ketidakpastian waktu dalam melakukan pelayanan membuat beberapa masyarakat malas untuk berhubungan langsung dengan instansiinstansi pemerintahan yang bersentuhan langsung oleh masyarakat. Hal ini di sebabkan karena adanya sebuah nilai-nilai kearifan yang hilang dari setiap pegawai.

Oleh karena pemerintah secara hakiki berfungsi membuat dan menerapkan kebijakan-kebijakan untuk mensejahterakan, mencerdaskan, memberdayakan, serta melindungi, seluruh masyarakatnya maka sangatlah bijak mengoptimalkan kearifan lokal dalam pelaksanaan pemerintahan. Kearifan lokal adalah semua bentuk pengetahuan, kayakinan, pemahaman, atau wawasan serta adat istriadat yang dimana sebuah kebiasaan atau etika masyarakat yang menuntun ke perilaku manusia didalam sebuah kumpulan ekologis. Semua bentuk kearifan lokal ini di hayati, di pratekkan, diajarkan dan diwariskan dari generasi kegenerasi sekaligus membentuk pola perilaku manusia terhadap sesama manusia (Keraf, 2002).

Nilai-nilai kearifan seharusnya menjadi salah satu penopang terciptanya sistem administrasi yang baik karena beberapa pegawai lupa akan apa yang telah diamanatkan untuk menciptakan sebuah pelayanan yang baik, untuk mencapai sebuah sistem pelayanan yang baik, maka nilai-nilai kearifan berperan sebagai landasan selain aturan yang tertulis dalam beberapa instansi pemerintah Kabupaten Bulukumba salah satunya yaitu di kantor Dinas Kependudukan dan Catatan Sipil Kabupaten Bulukumba.

Adapun di dalam undang undang nomor 32 tahun 2009 tentang Perlindungan dan Pengelolaan Lingkungan

Hidup, perlu menetapkan kebijakan dalam implementasi pengakuan hukum adat, kearifan lokal, dan hak masyarakat hukum adat yang terkait dengan perlindungan dan pengelolaan lingkungan hidup. Betapa besarnya pengaruh nilai-nilai kearifan lokal 
seperti nilai-nilai yang dianut oleh masyarakat Kabupaten Bulukumba seperti siri' na pacce, sipakainga', sipakatau hal ini sangatlah berpengaruh kepada kinerja pegawai di kantor catatan sipil Kabupaten Bulukumba. Sehingga perlunya pemerintah untuk mananamkan nilai-nilai kearifan lokal sebagai salah satu faktor pendukung meningkatnya kinerja pegawai ataupun menjadi sebuah norma-norma tidak tertulis namun menjadi faktor-faktor yang mempengaruhi kinerja para pegawai. Salah satu contoh yaitu: sipangngaliki (saling mengahargai).

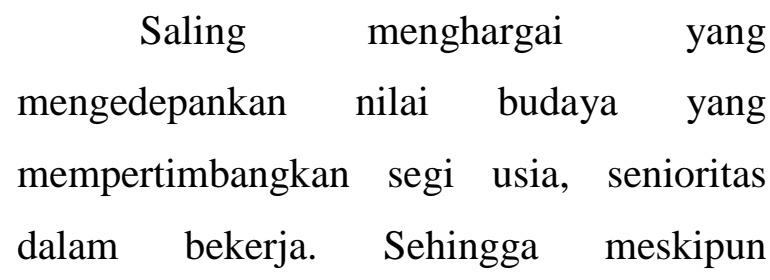
kedudukannya sebagai atasan tetapi dari segi usia atau senioritas lebih muda maka tetap menghargai dan menghormati yang lebih muda. Banyaknya sejumlah nilai budaya pada masyarakat yang telah mengalami sebuah perubahan dengan adanya cara menerapkan atau menirukan sebuah modernisasi di semua bidang kehidupan masyarakat, yaitu menyebabkan suatu kearifan lokal yang dapat tumbuh dan berkembang di kantor Dinas Kependudukan dan Catatan Sipil Kabupaten Bulukumba menjadi terkikis.

Kearifan lokal (local wisdom) pada dalam disiplin antropologi di kenal juga sebagai suatu istilahlocal genius. Local genius istilah yang pertama diperkenalkan oleh Quatrich Wales. (Ayatrohaedi,1986). Para antropologi telah menjelaskan bahwa pengertian local genius ini. Antara lain Haryati Soebadio mengatakan bahwa local genius ialah sebuah cultural identy, identitas atau sebuah kepribadian suatu budaya bangsa yang telah menyebabkan sebuah bangsa tersebut telah mampu mendalami dan mengelolah suatu kebudayaan asing yang sesuai dengan watak serta kemampuan sendiri (Ayatrohaedi, 1986). Sementara Moendardjito (Ayatroehaedi, 1986) mengatakan bahwa unsur budaya daerah potensial sebagai local genius karena telah teruji kemampuannya untuk bertahan sampai sekarang. Adapun beberapa Ciri-ciri kearifan lokal tersebut adalah sebagai berikut: 1) Mampu mempertahankan budaya adat terhadap budaya luar, 2) Memiliki kemampuan membantu bagian unsur-unsur budaya luar, 3) 
Memiliki kemampuan menyatukan budaya luar ke dalam budaya asli, 4) Mempunyai kemampuan mengendalikan, 5) Mampu memberi arah positif majunya perkembangan budaya.

Kearifan lokal juga dapat didefinisikan sebagai salah satu kekayaan budayaan lokal yang dapat mengandung beberapa kebijakan hidup, pandangan hidup (way of life) yang membantu atau mengakomodasi suatu kebijakan (wisdom), dan kearifan hidup. Di Indonesia kearifan lokal tidak hanya dapat berlaku secara lokal pada suatu budaya atau hanya etnik tertentu saja, akan tetapi dapat juga dikatan bersifat lintas budaya atau lintas etnik maka membentuk suatu nilai budaya yang sifatnya nasional. Sebagai contoh yaitu hampir disetiap budaya lokal di nusantara dapat dikenal kearifan lokalnya yang mengajarkan seperti gotong royong, toleransi, semangat kerja, dan seterusnya.

Pada umunya beberapa etika serta nilai moral yang terdapat di dalam kearifan lokal yang telah diajarkan turun menurun, diwariskan dari beberapa generasi ke generasi dengan melalui sastra lisan, antara lain ialah dalam bentuk pepatah dan pribahasa (Suyastno, 2014).

Adapun prosesevolusi yang sangat panjang dan melekat didalam masyarakat dapat dijadikan kearifan lokal sebagai sumber energi yang berpengaruh dari sebuah sistem pengetahuan yang kolektif untuk masyarakat yang hidup bersama secara aktif dan damai. Pengertian ini melihat kearifan lokal tidak hanya sekedar sebagai acuan atau tingkahlaku seseorang, akan tetapi jauh lebih mampu yaitu mendinamisasi beberapa kehidupan masyarakat yang sangat penuh keadaban.

Di jelaskan lebih jelas bahwa kearifan tercermin pada suatu keputusan yang positif dan permutu serta prima, dimana tolak ukur satu keputusan yang bermutu dan prima ialah suatu keputusan yang dimana dapat diambil oleh seorang atau tokoh sejumlah tokoh yang dengan cara menelusuri beberapa suatu maslah yang berkembang dan dapat memahami masalah tersebut (Ataupah, 2004).

Kearifan lokal tidaklah akan sama pada tempat serta waktu yang berbeda dan bahkan suku adat yang berbeda juga. Perbedaan ini disebabkan oleh beberapa tantangan alam 
serta beberapa kebutuhan hidupnya yang berbeda-beda, maka pengalamannya dalam memenuhi beberapa kebutuhan hidupnya memunculkan berbagai sistem pengetahuan yang baik yang berhubungan dengan lingkungan maupun sosial.

\section{Konsep Kinerja Pegawai}

Akhir-akhir ini kinerja telah menjadi terminology konsep yang sering dipakai orang dalam berbagai pembahasan dan pembicaraan, khususnya dalam kerangka mendorong keberhasilan organisasi atau sumber daya manusia. Terlebih saat ini organisasi dihadapkan pada tantangan kompetisi yang tinggi, era kompetisi pasar global, kemajuan teknologi informasi, maupun tuntutan pelanggan atau pengguna jasa layanan yang semakin kritis. Menurut Sudarmanto dalam Nuriana (2017:17).

Kinerja pegawai didefinisikan sebagai salah satu tingkat sebuah pencapaian hasil, maka kinerja organisasi ialah tingkat pencapaian hasil kerja dari sebuah tujuan organisasi. Rue dan Byars (Keban, 1995:67).

Robbins, dalam Nuriana (2017:18), dikatakan bahwa kinerja merupakan tolak ukur dalam melakukan suatu pekerjaan sedangkan, menurut Luthans, 2005 dalam
Nuriana (2017:18), kinerja adalah kuantitas atau kualitas sesuatu yang dihasilkan atau jasa yang diberikan oleh seseorang yang melakukan pekerjaan.

Kinerja pegawai didalam sebuah organisasi dapat mengarah kepada sebuah kemampuan pegawai dalam melaksanakan semua keseluruhan berbagai tugas-tugas yang menjadi tanggung jawabnya. Tugastugas tersebut dapat biasanya berdasarkan sebuah indikator indikator semua keberhasilan yang telah ditetapkan. Sebagai hasilnya akan diketahuibahwa dimana seseorang pegawai sudah masuk didalam tingkatan kinerja tertentu.

Bernardin, dalam Nuriana (2017: 19) menyampaikan ada 6 kriteria dasar atau dimensi untuk mengukur kinerja, yaitu: a) Quality terkait dengan proses atau hasil mendekati sempurna atau ideal dalam memenuhi maksud atau tujuan. b) Quantity terkait dengan satuan jumlah atau kuantitas yang dihasilkan. c) Timeliness terkaait dengan waktu yang diperlukan dalam menyelesaikan aktivitas atau menghasilkan produk. d) Cost-effectiveness terkait dengan tingkat pengguna sumber-sumber organisasi (orang, uang, material, teknologi) dalam 
mendapatkan atau memperoleh hasil atau pengurangan pemborosan dalam penggunaan sumber-sumber organisasi. e) Need for supervision terkait dengan kemamp uan individu dapat menyelesaikan pekerjaan atau fungsi-fungsi pekerjaan tanpa asistensi pimpinan atau intervensi pengawasan pimpinan. f) Interpersonal impact terkait dengan kemampuan individu dalam mening katkan perasaan harga diri keinginan baik dan kerjasama sesama pekerja dan anak buah.

Mitchell dalam Sedarmayanti (2011) menyatakan bahwa kinerja meliputi 5 aspek yaitu: a) Kualitas pekerjaan (Quality of work), yang terdiri dari komponen mutu hasil pekerjaan dan sikap dalam bekerja. b) Ketepatan waktu (promptness), yang terdiri dari komponen tingkat kehadiran dan pemanfaatan waktu luang. c) Inisiatif (Inisiative), yang terdiri dari komponen tingkat inisiatif dan tanggung jawab terhadap pekerjaan. d) Kecakapan (capability), yang terdiri dari komponen kehandalan dalam menyelesaikan tugas dan pengetahuan tentang pekerjaan. e) Komunikasi (comunication), yang terdiri dari komponen kejujuran dalam menyampaikan pendapat dan kerjasama dalam menyelesaikan pekerjaan.

Kinerja merupakan sebuah penampilan dari hasil karya seseorang dalam bentuk kualitas ataupun kuantitas didalam sebuah organisasi. Kinerja dapat merupakan sebuah penampilan individu maupun sebuah kelompok kerja pegawai. Adapun tiga hal terpenting dalam sebuah kinerja ialah tujuan, penilaian, serta ukuran. Penentuan suatu tujuan pasa setiap unit organisasi dapat merupakan strategi untuk meningkatkan kinerja, dimana tujuan ini akan memberikan beberapa arah dan mempengaruhi bagaimana yang seharusnya prilaku sebuah kerja yang diharapkan organisasi dari setiap personel. akan tetapi ternyata jika hanya tujuan saja itu tidak cukup, sebab itu diperlukan ukuran apakah seseorang personel telah tercapai kinerja yang diharapkan. Untuk itu penilaian kuantitaf dan kualitatif standar kinerja atau untuk pada setiap tugas dan jabatan personel memegang peranan yang sangat penting.

Akhir dari sebuah proses kinerja ialah sebuah penilaian itu sendiri yang dikaitkan dengan proses pencapaian tujuan. Jika ukuran pencapaian kinerja telah 
ditetapkan, maka sebuah langkah berikutnya ialah dalam mengukur sebuah kinerja adalah mengumpulkan informasi yang telah berhubungan dengan hal tersebut dari dengan standar yang telah dibuat oleh oleh periode waktu yang bersangkutan, akan didapatkan beberapa tingkat kinerja dari seorang pegawai. Secara singkatnya dapat dikatakan bahwa pengukuran tentang sebuah kinerja pegawai tergantung kepada jenis pekerjaannya serta tujuan dari sebuah organisasi yang bersangkutan.

\section{METODE PENELITIAN}

Penelitian ini menggunakan jenis penelitian kuantitatif, penelitian yang manfaatnya dirasakan untuk jangka panjang lamanya karena penelitian ini biasanya dilakukan untuk kebutuhan peniliti sendiri. Populasi penelitian ini adalah seluruh pegawai yang ada di Kantor Dinas Dan Catatan Sipil Kabupaten Bulukumba yaitu sebanyak 93 pegawai, yang terdiri dari pegawai negri sipil (PNS), pegawai honorer, dan pegawai operator kecamatan. peneliti menentukan sampel dengan menggunakan teknik sampling jenuh, yaitu teknik penentuan sampel bila semua anggota populasi digunakan sebagai sampel. Dengan demikian, maka yang menjadi sampel dalam penelitian ini adalah seluruh pegawai di Kantor Dinas Kependudukan dan Catatan Sipil Kabupaten Bulukumba sebanyak 93 orang. Teknik pengumpulan data yang peneliti gunakan yaitu: Observasi, Wawancara dan Dokumentasi. Penulis menggunakan metode analisis data sebagai berikut: analisis regresi sederhana, metode analisis deskriptif, uji normalitas, uji validitas dan uji reliabilitas.

\section{HASIL DAN PEMBAHASAN}

Dinas Kependudukan dan Catatan Sipil merupakan unsur pelaksana otonomi daerah berdasarkan Undang-Undang Nomor 29 Tahun 1959 tentang Pembentukan Daerah-Daerah Tingkat II di Sulawesi (Lembaran Negara RI Tahun 1959 Nomor 74, Tambahan Lembaran Negara Nomor 1822); Undang-Undang Nomor 8 Tahun 1974 tentang Pokok-Pokok Kepegawaian (Lembaran Negara RI Tahun 1974 Nomor 55, Tambahan Lembaran Negara Nomor 3041), sebagaimana telah diubah dengan Undang-ndang Nomor 43 Tahun 1999 (Lembaran Negara RI Tahun 1999 Nomor 169, Tambahan Lembaran Negara Nomor 
3890);. Sebelum menjadi dinas Pelayanan Kependudukan dan Pencatatan Sipil dilakukan oleh Kantor Kependudukan dan Catatan Sipil.

Lembaga ini bertugas untuk mencatat dan mendaftarkan setiap peristiwa kependudukan yang dialami oleh warga Negara/masyarakat yang dimulai dari perubahan alamat, pindah datang untuk menetap, tinggal terbatas, serta perubahan status orang asing tinggal terbatas menjadi tinggal tetap dan peristiwa penting antara lain kelahiran, perkawinan, perceraian, kematian, termasuk pengakuan, pengangkatan dan pengesahan anak, perubahan status kewarganegaraan, ganti nama dan peristiwa kependudukan penting lainnya yang dialami oleh seseorang merupakan kejadian yang harus dilaporkan karena mengalami implikasi perubahan data identitas serta surat keterangan kependudukan.

\section{Memperhatikan}

penduduk dan pertumbuhan ketatanegaraan dan warganya sangat mempengaruhi arti penting dokumen kependudkan dan catatan sipil bagi setiap warga Negara Indonesia.
Pengambilan sampel yang dilakukan penulis di Kantor Dinas Kependudukan dan Catatan Sipil Kabupaten Bulukumba yaitu sampel jenuh dimana yang menjadi responden dalam penelitian ini adalah seluruh Pegawai Kantor Dinas Kependudukan dan Catatan Sipil Kabupaten Bulukumba sebanyak 93 orang. jumlah responden berdasarkan jenis kelamin lakilaki sebanyak 49 orang atau $54 \%$ sedangkan yang berjenis kelamin perempuan sebesar 44 orang atau $46 \%$.

Pada penelitian ini penulis memberikan batasan umur pada responden dari 25 tahun sampai 60 tahun. Penulis memberi batasan umur mulai 25 tahun karena pada usia tersebut sudah masuk dalam usia produktif dan pada usia 60 tahun ke atas itu sudah masuk dalam usia tidak produktif. dimana responden yang berumur 25 - 30 tahun sebanyak 16 orang atau 17,2 $\%$, usia $31-40$ sebanyak 49 orang atau 52,7 $\%$, usia $41-50$ sebanyak 28 orang atau 30,1 $\%$. Dengan hasil ini dapat disimpulkan bahwa responden berdasarkan umur terbanyak pada penelitian ini umur $31-40$ sebanyak 49 orang. karakterisrik responden berdasarkan tingkat pendidikan dimana 
responden yang tidak tamat SMP sebanyak 1 orang atau $1 \%$ sedangkan yang berpendidikan SMA sebanyak 24 orang atau $25,8 \%$, dan S1 sebanyak 65 orang atau 70,2 $\%$ Dengan hasil ini dapat disimpulkan bahwa rata-rata responden berpendidikan $\mathrm{S} 1$

pada penelitian ini

Nilai-nilai kearifan lokal (X) adalah

Siri' na pacce, Sipakainga' dan Sipakatau. Variabel $\mathrm{X}$ indikator nilai-nlai kearifan dapat disimpulkan bahwaindikator nilai-nilai kearifan di Kantor Dinas
Bulukumba masuk dalam kategori "sangat tinggi” berpengaruh terhadap kinerja pegawai di Kantor Dinas Kependudukan dan Catatan Sipil Kabupaten Bulukumba. Hal ini sebabkan oleh, para pegawai di kantor Dinas Kependudukan dan Catatan Sipil kabupaten Bulukumba masih memegang teguh dan menjunjung tinggi nilai-nilai kearifan lokal dalam bekerja ataupun berinteraksi dengan masyarakat.

\section{Hasil Uji Regresi Sederhana}

Nilai Kearifan Lokal Terhadap Kinerja

Pegawai

\begin{tabular}{lllllll}
\hline \multirow{2}{*}{ Model } & & \multicolumn{5}{c}{ Standardized } \\
Unstandardized Coefficients & Coefficients & & \\
\cline { 2 - 5 } & & $\mathrm{B}$ & Std. Error & Beta & & \multicolumn{1}{c}{ Sig. } \\
\hline 1 & (Constant) & 58.376 & 3.497 & & 16.691 & .000 \\
\cline { 2 - 6 } & Kearifan Lokal & .089 & .165 & .056 & .538 & .592 \\
\hline
\end{tabular}

Kependudukan dan Catatan Sipil

Sumber: SPSS Versi 21

Kabupaten Bulukumba di dapatkan nilai rata-rata $70 \%$ nilai tersebut di dapatkan dari jumlah skor responden di bagi jumlah skor ideal di kali 100. Hasil dari rata-rata tersebut yaitu dapat di simpulkan bahwa indikator pengaruh nilai-nilai kearifan lokal terhadap kinerja pegawai di kantor Dinas Kependudukan dan Catatan Sipil Kabupaten

Kinerja pegawai (Y) antara lain, kualitas pekerjaan, ketepatan waktu, inisiatif, kecakapan dan komunikatif. keseluruhan variabel $\mathrm{Y}$ indikator kinerja pegawai dapat disimpulkan bahwa indikator kinerja pegawai di Kantor Dinas Kependudukan dan Catatan Sipil Kabupaten 
Bulukumba di dapatkan nilai rata-rata 75,\% nilai tersebut di dapatkan dari jumlah skor responden di bagi jumlah skor ideal di kali 100. Hasil dari rata-rata tersebut yaitu dapat di simpulkan bahwa indikator pengaruh kinerja pegawai di Kantor Dinas Kependudukan dan Catatan Sipil Kabupaten Bulukumba masuk dalam kategori "sangat tinggi" berpengaruh di Kantor Dinas Kependudukan dan Catatan Sipil Kabupaten Bulukumba. Hal ini di sebabkan oleh kinerja pegawai yang begitu maksimal dalam bekerja dan menjalani pekerjaannya dengan sepenuh hati yang takut melakukan kesalahan dan menganggap kepuasan masyarakat dalam mendapatkan pelayanan adalah landasan bahwa para pegawai sukses dalam melakukan pekerjaan.

Berdasarkan tabel 4.31 maka diperoleh rumus regresi sederhana sebagai berikut:

$$
\begin{gathered}
\mathrm{Y}=\mathbf{a}+\mathbf{b X} \\
\mathrm{Y}=\mathbf{5 8 , 3 7 6}+\mathbf{0 , 0 8 9 X}
\end{gathered}
$$

Berdasarkan persamaan diatas maka diperoleh nilai konstan positif sebesar 58,376 . Hal ini menunjukkan jika variabel nilai kearifan lokal konstan atau sama dengan nol (0), maka nilai kinerja pegawai bernilai 58,376. Sedangkan koefisien regresi kearifan lokal bernilai positif yaitu 0,089. Hal ini menunjukkan bahwa nilai kearifan lokal berpengaruh positif terhadap kinerja pegawai di Kantor Dinas Kependudukan dan Catatan Sipil Kabupaten Bulukumba. Artinya jika Variabel nilai kearifan lokal ditingkatkan maka kinerja pegawai akan meningkat.

Berdasarkan hasil uji regresi sederhana yang telah dilakukan diatas, maka didapatkan hasil penelitian yaitu nilai - nilai kearifan lokal berpengaruh positif tidak signifikan. Hal ini dibuktikan dengan hasil nilai regresi sebesar positif 0,089 dengan tingkat signifikan 0,592 lebih besar dari 0,05 . Hasil ini diperkuat dengan hasil uji kofisien determinasi sebesar 0,073 atau 7,3 $\%$ kontribusi nilai kearifan lokal terhadap kinerja pegawai di Kantor Dinas Kependudukan dan Pencatatan Sipil Kabupaten Bulukumba.

Sedangkan 92,7\% dipengaruhi oleh faktor lain yang tidak diteliti pada penelitian kali ini. Berdasarkan hasil penjumlahan secara keseluruhan variabel $\mathrm{X}$ indikator nilai-nlai kearifan dapat disimpulkan bahwa indikator nilai-nilai kearifan di dapatkan 
nilai rata-rata $70,18 \%$ atau termasuk dalam kategori sangat tinggi.

Berdasarkan nilai kearifan lokal skoring di atas, dapat di simpulkan bahwa Indikator Pengaruh Nilai-Nilai Di Kantor Dinas Kependudukan dan Catatn Sipil Kabupaten Bulukumba mendapatkan skor $70,18 \%$ atau berada dalam kategori "sangat tinggi" berpengaruh terhadap kinerja pegawai di Kantor Dinas Kependudukan dan Catatan Sipil kabupaten Bulukumba. Hal ini sebabkan oleh, para pegawai di kantor Dinas Kependudukan dan Catatan Sipil Kabupaten Bulukumba masih memegang teguh dan menjunjung tinggi nilai-nilai kearifan lokal dalam bekerja ataupun berinteraksi dengan masyarakat.

Berdasarkan hasil penjumlahan secara keseluruhan variabel $\mathrm{Y}$ indikator kinerja pegawai dapat disimpulkan bahwa indikator kinerja pegawai mendapatkan nilai rata-rata $75 \%$ atau berada dalam kategori sangat tinggi.

Berdasarkan tabel di atas, dapat di simpulkan bahwa indikator kinerja pegawai di Kantor Dinas Kependudukan dan Catatan Sipil Kabupaten Bulukumba memperoleh skor $75 \%$ atau dalam kategori "sangat tinggi” berpengaruh di Kantor Dinas Kependudukan dan Catatan Sipil kabupaten Bulukumba. Hal ini di sebabkan oleh kinerja pegawai yang begitu maksimal dalam bekerja dan menjalankan pekerjaan dengan sepenuh hati yang takut melakukan kesalahan dan menganggap kepuasan masyarakat dalam mendapatkan pelayanan adalah landasan bahwa para pegawai sukses dalam melakukan pekerjaan.

Berdasarkan hasil observasi yang di lakukan oleh peneleiti di dapati beberapa faktor yang sangat berpengaruh satu sama lain antara kinerja pegawai dan nilai-nilai kearifan sebagai penunjang terciptanya kinerja pegawai yang baik di kantor Dinas Kependudukan dan Catatan Sipil Kabupaten Bulukumba "sangat tinggi" Karena nilainilai kearifan lokal yang masih di pegang teguh oleh masyarakat Bulukumba dan para pegawai di Kantor Dinas Kependudukan dan Catatan Sipil Kabupaten Bulukumba penerapan nilai-nilai kearifan lokal berpengaruh baik apabila di aplikasikan dalam melakukan pekerjaan contohnya yaitu siri' na pace pengaplikasian siri' na pace dalam melakukan pekerjaan sangat baik, karena para pegawai takut untuk melakukan 
penyimpangan dari apa yang seharusnya dilakukan oleh para pegawai dalam menjalankan amanah pekerjaan yang di embannya inilah yang mempengaruhi "sangat tinggi" kinerja pegawai di Kantor

Dinas Kependudukan dan Catatan Sipil Kabupaten Bulukumba.

Hasil penelitian ini mendukung penelitian yang di lakukan oleh Wardani dan Mukzam (2016) dengan hasil penelitiann budaya organisasi pengaruh positif dan signifikan terhadap kinerja pegawai PT. Karya Indah Buana Surabaya. Sedangkan penelitian ini bertolak belakang dengan hasil penelitian yang dilakukan oleh Hasluna (2014) dengan hasil penelitian tidak terdapat hubungan yang positif dan signifikan antara budaya organisasi dan kinerja pegawai Balai Pelestarian Nilai Budaya Tanjung pinang.

\section{KESIMPULAN}

Berdasarkan hasil penelitian yang dilakukan mengenai pengaruh nilai-nilai kearifan lokal terhadap kinerja pegawai di Kantor Dinas Kependudukan Dan Catatan Sipil Kabupaten Bulukumba, maka dapat disimpulkan bahwa: Nilai-nilai kearifan lokal sudah berjalan dengan baik di Kantor
Dinas Kependudukan dan Catatan Sipil Kabupaten Bulukumba. Hal ini dibuktikan dengan hasil penjumlahan kuesioner dengan indikator nilai-nilai kearifan lokal sebesar $70,18 \%$ atau termasuk dalam kategori sangat tinggi. Kinerja pegawai di Kantor Kantor Dinas Kependudukan dan Catatan Sipil Kabupaten Bulukumba sudah berjalan dengan baik. Hal ini dibuktikan dengan hasil penjumlahan kuesioner dengan indikator kinerja pegawai sebesar $75 \%$ atau berada dalam kategori sangat tinggi.

Nilai kearifan lokal berpengaruh secara positif dan tidak signifikan. Hal ini dibuktikan dengan hasil nilai regresi sebesar positif 0,089 dengan tingkat signifikan 0,592 lebih besar dari 0,05. Hasil ini diperkuat dengan hasil uji koefisien determinasi sebesar 0,073 atau $7,3 \%$ kontribusi kontribusi nilai kearifan lokal terhadap kinerja pegawai di Kantor Dinas Kependudukan dan Pencatatan Sipil Kabupaten Bulukumba. Sedangkan 92,7\% dipengaruhi oleh faktor lain yang tidak diteliti pada penelitian kali ini. Uji f, dimana hasil uji menunjukkan nilai f sebesar 0,290 dengan tingkat signifikan 0,592 dan uji $\mathrm{t}$ 
sebesar 0,538 dengan tingkat signifikan sebesar 0,592.

Untuk meningkatkan kinerja pegawai di Kantor Dinas Kependudukan dan Catatan Sipil Kabupaten Bulukumba para pegwai harus lebih mengedepankan aspek nilai nilai kearifan lokal supaya lebih efisien dalam me lakukan pekerjaan. Untuk penelitian selanjut nya untuk menambah variabel yang dapat mempengaruhi kinerja karyawan yang tidak diteliti pada penelitian kali ini.

\section{DAFTAR PUSTAKA}

Abdullah, Ma'ruf. 2015, Metodologi Penelitian Kuantitatif, Aswaja pressindo.

Faozan dkk. 2001. Pelayanan publik Dan Customer Satisfaction, Bandung: PT. ALUMNI.

Gasperz, Vincent. 2002, ISO 9001:2000 And Continual Quality Improvement, Jakarta: PT. Gramedia Pustaka Utama.

Hardiyansyah. 2011, Kualitas Pelayanan Publik Konsep, Dimensi, Indikator, dan

Implementasinya, Yogyakarta: Gava Media.

Keputusan Menteri Pendayagunaan Aparatur Negara Nomor: KEP/25/M.PAN/2/2004 tentang Pedoman Umum Penyusunan Indeks Kepuasan Masyarakat.

Keputusan Menteri Pendayagunaan Aparatur Negara Nomor: 63/KEP/M.PAN/7/2003 tentang Pedoman Umum Penyelenggaraan Pelayanan Publik

Nasution, Nur. 2002. Manajemen Mutu Terpadu (TQM), Edisi Kedua, Ciawi: Ghalia Indonesia.

Rafiq Muhammad, Aswin Jurnal Bisnis Darmajaya, Vol.01. No.02, Juli 2015 Analisis dampak penerapan manajemen mutu ISO 9001: 2008 terhadap kualitas pelayanan akademik perguruan tinggi di Bandar lampung

Sugiyono, 2017 Metode Penelitian Kuantitatif, Kualitatif dan $R \& D$ cetakan ke-25, Bandung: Alfabeta.

Tjiptono, Fandy. 2005. Prinsip-Prinsip Total Quality Service, Yogyakarta: ANDI 